\title{
SYNTHESIS OF HOLMIUM ORTHOFERRITE NANOPARTICLES BY THE CO-PRECIPITATION METHOD AT HIGH TEMPERATURE
}

\author{
Nguyen Anh Tien ${ }^{l}$, Truong Chi Hien ${ }^{l}$, Bui Xuan Vuong ${ }^{2, *}$

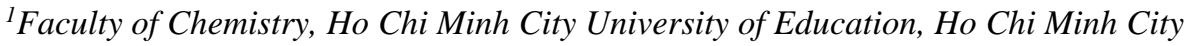 \\ 700000, Vietnam \\ ${ }^{2}$ Faculty of Pedagogy in Natural Sciences, Sai Gon University, Ho Chi Minh City \\ 700000, Vietnam
}

Received 21.01.2021

Accepted 25.05.2021

\begin{abstract}
Holmium orthoferrite $\mathrm{HoFeO}_{3}$ nanoparticles were synthesized by a simple coprecipitation method via the hydrolysis of Ho (III) and Fe (III) cations in boiling water with $5 \%$ aqueous ammonia solution. After annealing the precipitate at 750 and $850{ }^{\circ} \mathrm{C}$ for 1 hour, the single-phase $\mathrm{HoFeO}_{3}$ product formed with particle size $<50 \mathrm{~nm}$. The synthesized nanopowders are paramagnetic materials with remanent magnetization $\mathrm{M}_{\mathrm{r}}<$ $0.01 \mathrm{emu} \cdot \mathrm{g}^{-1}$, the coercive force $\mathrm{H}_{\mathrm{c}}=20 \div 21 \mathrm{Oe}$, and magnetization $\mathrm{M}_{\mathrm{s}} \sim 2.73 \mathrm{emu} \cdot \mathrm{g}^{-1}$ at $300 \mathrm{~K}$ in a maximum field of $16,000 \mathrm{Oe}$.
\end{abstract}

Keywords: $\mathrm{HoFeO}_{3}$; nanoparticles; magnetic properties; co-precipitation.

\section{Introduction}

Out of the vast class of multifunctional materials, orthoferrites of rare-earth elements with a perovskite structure $\left(\mathrm{RFeO}_{3}\right)$, including holmium orthoferrite, have garnered much attention for use in modern technologies [1-8]. Rare-earth orthoferrite nanoparticles were obtained and used in some areas, such as photocatalysts [3, 8], chemical sensors [4], solid fuel cells [7], magneto-optical devices [1], and electromagnetic equipment [6,9]. Holmium orthoferrite with a perovskite structure $\left(\mathrm{HoFeO}_{3}\right)$ is a promising functional material exhibiting ferromagnetic properties and high catalytic activity $[8,10-13]$.

In the study [8], holmium orthoferrite nanocrystals $\left(\mathrm{HoFeO}_{3}\right)$ with an average size of $27-40 \mathrm{~nm}$ (according to the XRD results) obtained by a combustion method using glycine were used to decompose methyl orange in visible light due to its narrow energy gap $\left(\mathrm{E}_{\mathrm{g}}=2.12-2.14 \mathrm{eV}\right) . \mathrm{HoFeO}_{3}$ orthoferrite with a particle size of $149.30 \mathrm{~nm}(\mathrm{SEM})$, obtained by the ceramic method from the corresponding holmium and iron (III) oxides,

${ }^{*}$ Corresponding author: Bui Xuan Vuong, buixuanvuongsgu@gmail.com 
was characterized by saturation magnetization $\mathrm{M}_{\mathrm{s}}=25.5 \mathrm{emu} \cdot \mathrm{g}^{-1}$, remanent magnetization $\mathrm{M}_{\mathrm{r}}=4.08 \mathrm{emu} \cdot \mathrm{g}^{-1}$, and a very high coercive force $\mathrm{H}_{\mathrm{c}}=2659$ Oe at $10 \mathrm{~K}$ in a maximum field of $60,000 \mathrm{Oe}$ [10]. The $\mathrm{HoFeO}_{3}$ obtained in this study is a magnetically hard material $\left(\mathrm{H}_{\mathrm{c}}>100 \mathrm{Oe}\right)[14]$; it can be used for the production of electromagnets, magnetic tapes, and magnetic recording materials. However, the magnetic characteristics of this material not only depend on the nature of the compound and its crystalline structure but also depend on the size of particles, their morphology, impurity content, and the synthesis method [10, 14-18].

Various methods have been developed for the formation of nanocrystalline holmium orthoferrite $\left(\mathrm{HoFeO}_{3}\right)$. These methods included a mechanochemical method with a high annealing temperature (usually $>1200{ }^{\circ} \mathrm{C}$ ) $[10,15]$, hydrothermal synthesis with a long heating time (usually 12-48 h) [11], sol-gel technology in compliance with several influencing factors $[8,12]$ and even the formation under the influence of gamma radiation with modern equipment [19-20].

Several studies [21-26] described the features of the formation of $\mathrm{RFeO}_{3}$ orthoferrite nanoparticles $(\mathrm{R}=\mathrm{La}, \mathrm{Y}, \mathrm{Nd}$ ) and doped with metal cations (for example, $\mathrm{Mn}, \mathrm{Ni}, \mathrm{Co}$ ) by a simple co-deposition method via the hydrolysis of cations in boiling water $\left(\mathrm{t}^{\circ}>90^{\circ} \mathrm{C}\right)$, followed by the addition of the corresponding precipitators. This kind of strategy has been supposed to stabilize the obtained precipitate. Thus, it results in the controllable growth of crystals better than the co-precipitation at room temperature [2122]. $\mathrm{HoFeO}_{3}$ nanoparticles have not been synthesized yet by similar methods. $\mathrm{HoFeO}_{3}$ was also prepared by co-precipitation, using ethanol [27]. However, ethanol is volatile, pollutant, and flammable solvent compared to water solvent. Furthermore, the water solvent is cheaper.

This study aimed to synthesize holmium orthoferrite nanoparticles with narrow values of coercive force, remanent magnetization, and a high value of saturation magnetization by co-precipitation method in the water solvent and at high temperature.

\section{Experimental}

As starting materials, we used $\mathrm{Ho}\left(\mathrm{NO}_{3}\right)_{3} \cdot 5 \mathrm{H}_{2} \mathrm{O}, \mathrm{Fe}\left(\mathrm{NO}_{3}\right)_{3} \cdot 9 \mathrm{H}_{2} \mathrm{O}, 25 \%$ an ammonia solution with a density of $\mathrm{d}=0.901 \mathrm{~g} . \mathrm{mL}^{-1}$ (all reagents were of CP grade), and distilled water. Solutions of holmium (III) and iron (III) nitrate were prepared by dissolving the corresponding salts in distilled water at room temperature $(300 \mathrm{~K})$. Boiling water $(400$ $\mathrm{mL}$ ) was slowly added to the equimolar mixture $(50 \mathrm{~mL})$ of $0.1 \mathrm{M} \mathrm{Ho}\left(\mathrm{NO}_{3}\right)_{3}$ and $0.1 \mathrm{M}$ $\mathrm{Fe}\left(\mathrm{NO}_{3}\right)_{3}$ solutions under continuously stirring with a magnetic stirrer $(4000 \mathrm{rpm})$. After addition, the mixture of salt solutions was boiled for $10 \mathrm{~min}$; then, under continuous stirring with a magnetic stirrer (4000 rpm), a 5\% ammonia aqueous solution was dropped appropriately as a precipitant to complete precipitation of Ho (III) and Fe (III) cations (phenolphthalein test). Continuously, the mixture solution was stirred for more than 60 min. The precipitates were collected on a vacuum filter, washed with distilled water to a $\mathrm{pH}$ value of $\sim 7.0$, and dried at room temperature to constant weight (for approximately three days). The dried precipitate was homogenized and subjected to complex thermal analysis (Labsys Evo TG-DSC $1600{ }^{\circ} \mathrm{C}$ ) with a heating rate of $10 \mathrm{deg} \cdot \mathrm{min}^{-1}$ in an atmosphere of dry air up to $1000{ }^{\circ} \mathrm{C}$ in order to establish the optimal annealing regime, providing the formation of single-phase $\mathrm{HoFeO}_{3}$.

The following methods were used to comprehensively study the characteristics of the obtained nanopowders: the phase composition and crystal structure were studied by 
X-ray diffraction (XRD; D8-ADVANCE diffractometer) with $\mathrm{CuK} \alpha$ radiation $(\lambda=1.540$ $\AA$ ) and Raman spectrometry (Horiba XploRA ONE); qualitative and quantitative elemental composition were studied by local X-ray microanalysis (XRM; scanning electron microscope FESEM S-4800), morphology and particle size were investigated by transmission electron microscopy (TEM; JEOL-1400); the average crystal size was determined according to the Debye Scherrer equation; parameters a, b, c and unit cell volume $\mathrm{V}$ of the were determined using the Rietveld method, implemented in the $\mathrm{X}$ 'pert High Score Plus 2.2b software package, saturation magnetization in the maximal field, remanent magnetization and coercive force were determined using VSM MICROSENE EV11 magnetometer.

\section{Results and discussion}

The complex thermal analysis of the $\mathrm{HoFeO}_{3}$ sample obtained by the coprecipitation of holmium (III) and iron (III) hydroxides showed (Fig. 1a) that the mass loss was $\sim 36.50 \%$, which is much higher than the one $(16.73 \%)$ calculated according to the reaction equation (1):

$$
\mathrm{Ho}(\mathrm{OH})_{3}+\mathrm{Fe}(\mathrm{OH})_{3} \rightarrow \mathrm{HoFeO}_{3}+3 \mathrm{H}_{2} \mathrm{O}
$$

This difference is caused by the result of co-precipitation consisting not only hydroxides $\left(\left(\mathrm{Fe}_{2} \mathrm{O}_{3} \cdot \mathrm{xH}_{2} \mathrm{O}\right.\right.$ [28] and $\mathrm{HoO}(\mathrm{OH}) \cdot \mathrm{yH}_{2} \mathrm{O}$ [28] $)$ but also carbonates $\left(\mathrm{Ho}_{2}\left(\mathrm{CO}_{3}\right)_{3} \cdot 8 \mathrm{H}_{2} \mathrm{O}\right.$ or $\left.\mathrm{Ho}_{2} \mathrm{O}\left(\mathrm{CO}_{3}\right)_{2} \cdot 1.4 \mathrm{H}_{2} \mathrm{O}\right)$ [29-30]. The presence of carbonates in the sample was probably associated with the dissolution of carbon dioxide (air) in an ammonia solution. A similar observation was reported in our previous paper for systems based on $\mathrm{YFeO}_{3}$ and $\mathrm{LaFeO}_{3}[21-22,24,26]$.

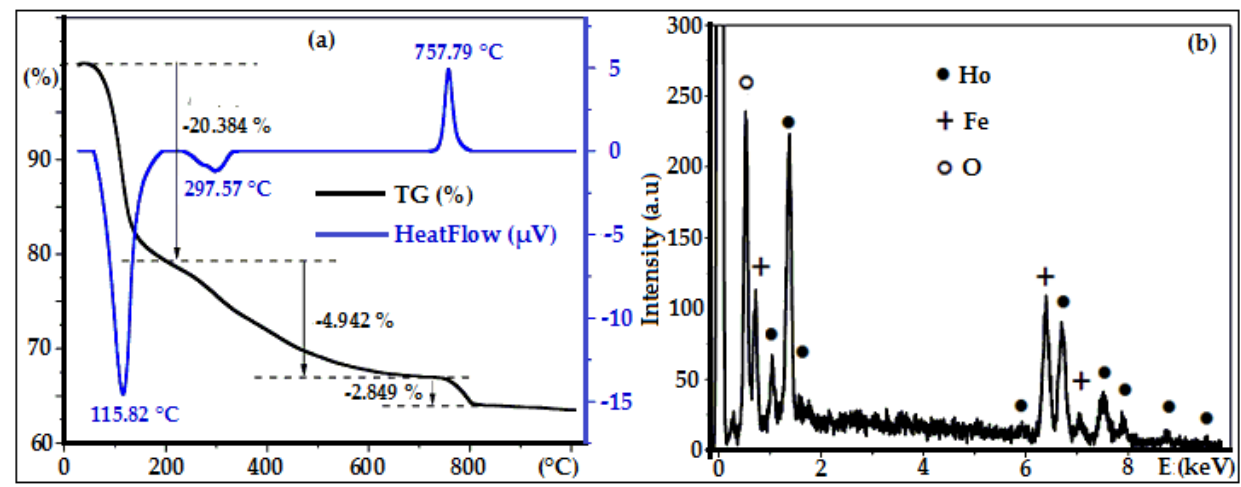

Fig. 1. TGA/DSC diagrams of the precipitate containing Ho (III) and Fe (III) (molar ratio of $\mathrm{Ho}^{3+}$ to $\mathrm{Fe}^{3+}$ is 1/1) (a), and Energy-dispersive $\mathrm{X}$-ray spectroscopy (EDX) of

$\mathrm{HoFeO}_{3}$ nanoparticles annealed at $850^{\circ} \mathrm{C}$ for $1 \mathrm{~h}$ (b).

The most significant mass loss (about 31.50\%) observed in the range of 60-500 ${ }^{\circ} \mathrm{C}$ was accompanied with two endothermic peaks at 115.82 and $297.57{ }^{\circ} \mathrm{C}$ (Fig. 1a), which is assigned for water evaporation, and decomposition of holmium (III), iron (III) hydroxides. The dehydration started at $50{ }^{\circ} \mathrm{C}$ and finished at around $100{ }^{\circ} \mathrm{C}$. On the other hand, the pyrolysis of iron (III) hydroxide and holmium hydroxide terminated at around 
$330{ }^{\circ} \mathrm{C}, 500{ }^{\circ} \mathrm{C}$, respectively $[28,32]$. Similarly, in our previous study, the pyrolysis of lanthanum hydroxide was also observed at approximately $500{ }^{\circ} \mathrm{C}$ [21].

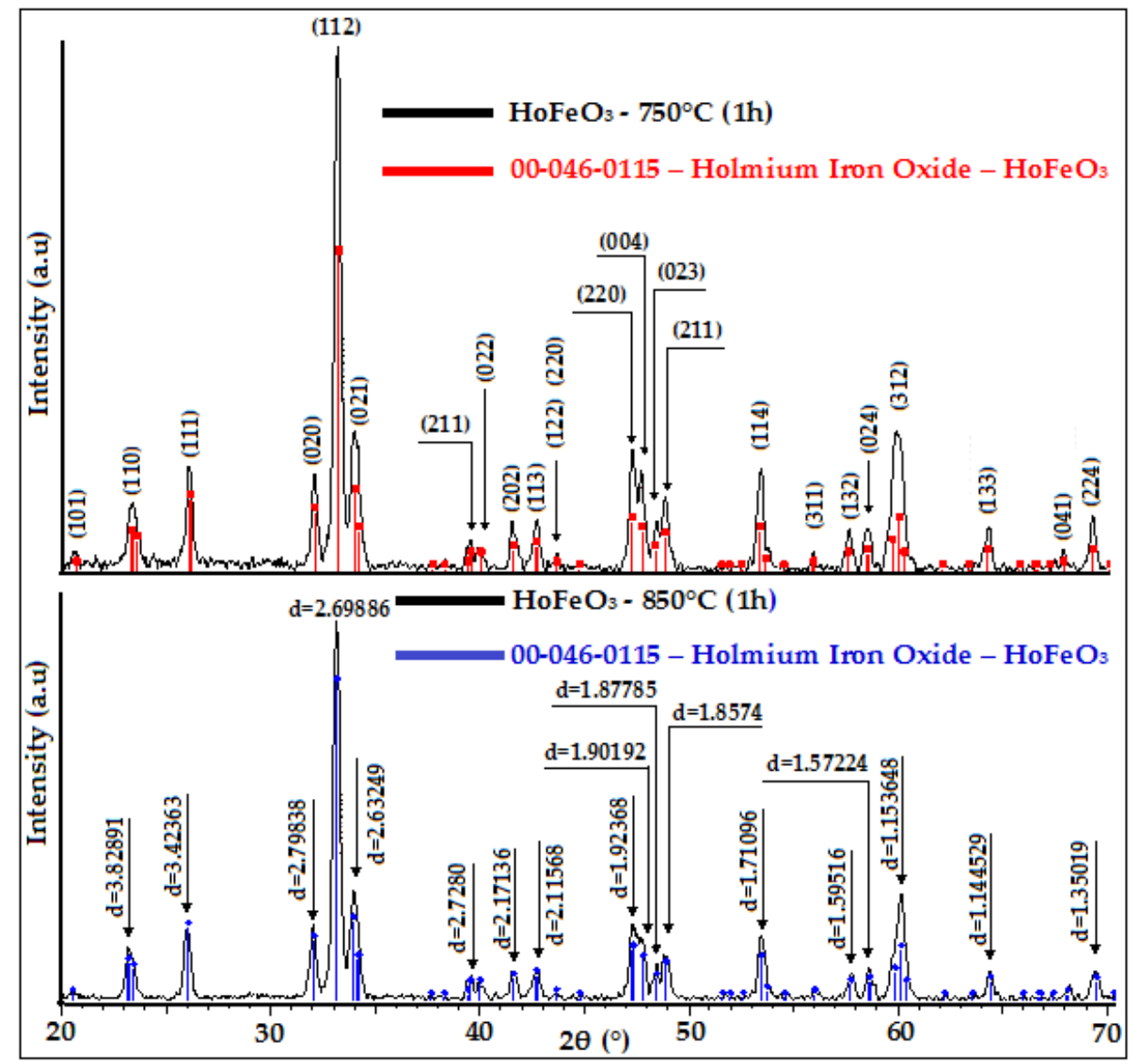

Fig. 2. XRD patterns of $\mathrm{HoFeO}_{3}$ formed at $750^{\circ} \mathrm{C}$ and $850^{\circ} \mathrm{C}$ for $1 \mathrm{~h}$.

The second mass loss observed in the range of $500-800{ }^{\circ} \mathrm{C}$ was related to the decomposition of holmium carbonates $\left(\mathrm{Ho}_{2}\left(\mathrm{CO}_{3}\right)_{3} \cdot 8 \mathrm{H}_{2} \mathrm{O}\right.$ or $\left.\mathrm{Ho}_{2} \mathrm{O}\left(\mathrm{CO}_{3}\right)_{2} \cdot 1.4 \mathrm{H}_{2} \mathrm{O}\right)$. We haven't observed any endothermic peak related to this phenomenon. Simultaneously, the crystallization of holmium orthoferrite nanoparticles $\left(\mathrm{HoFeO}_{3}\right)$ occurred at the temperature range of $750{ }^{\circ} \mathrm{C}-800{ }^{\circ} \mathrm{C}$, resulting in an obviously exothermic peak on the DSC diagram at $757{ }^{\circ} \mathrm{C}$. Probably, the absence of an endothermic peak on the DSC thermogram in the temperature range of $500-800{ }^{\circ} \mathrm{C}$ corresponding to the decomposition of holmium carbonates is due to the more significant crystallization of holmium orthoferrite nanoparticles. The crystallization was confirmed by the diffraction pattern of the sample after annealing at $750{ }^{\circ} \mathrm{C}$, which was a single-phase product, $\mathrm{HoFeO}_{3}$ (Fig. 2).

Briefly, the formation of single-phase of orthoferrite holmium $\left(\mathrm{HoFeO}_{3}\right)$ can be described as below equations [28-30, 32]. 


$$
\begin{aligned}
& 2 \mathrm{Fe}^{3+}+6 \mathrm{OH}^{-}+\mathrm{xH}_{2} \mathrm{O} \rightarrow \mathrm{Fe}_{2} \mathrm{O}_{3} \cdot(\mathrm{x}+3) \mathrm{H}_{2} \mathrm{O} \stackrel{<330^{\circ} \mathrm{C}}{\longrightarrow} \mathrm{Fe}_{2} \mathrm{O}_{3}+(\mathrm{x}+3) \mathrm{H}_{2} \mathrm{O} \\
& 4 \mathrm{Ho}^{3+}+12 \mathrm{OH}^{-}+3 \mathrm{CO}_{2}+\mathrm{xH}_{2} \mathrm{O} \rightarrow \mathrm{Ho}_{2}\left(\mathrm{CO}_{3}\right)_{3} \cdot 2 \mathrm{Ho}(\mathrm{OH})_{3} \cdot(\mathrm{x}+3) \mathrm{H}_{2} \mathrm{O} \\
& \mathrm{Ho}_{2}\left(\mathrm{CO}_{3}\right)_{3} \cdot 2 \mathrm{Ho}(\mathrm{OH})_{3} \cdot(\mathrm{x}+3) \mathrm{H}_{2} \mathrm{O} \stackrel{100^{\circ} \mathrm{C}}{\longrightarrow} \mathrm{Ho}_{2}\left(\mathrm{CO}_{3}\right)_{3} \cdot 2 \mathrm{Ho}(\mathrm{OH})_{3} \\
& \mathrm{Ho}_{2}\left(\mathrm{CO}_{3}\right)_{3} \cdot 2 \mathrm{Ho}(\mathrm{OH})_{3} \stackrel{<500^{\circ} \mathrm{C}}{\longrightarrow} \mathrm{Ho}_{2}\left(\mathrm{CO}_{3}\right)_{3}+\mathrm{Ho}_{2} \mathrm{O}_{3}+3 \mathrm{H}_{2} \mathrm{O} \\
& \mathrm{Ho}_{2}\left(\mathrm{CO}_{3}\right)_{3} \stackrel{500-800^{\circ} \mathrm{C}}{\longrightarrow} \mathrm{Ho}_{2} \mathrm{O}_{3}+3 \mathrm{CO}_{2} \\
& \mathrm{Ho}_{2} \mathrm{O}_{3}+\mathrm{Fe}_{2} \mathrm{O}_{3} \stackrel{750-850^{\circ} \mathrm{C}}{\longrightarrow} \mathrm{HoFeO}_{3}
\end{aligned}
$$

XRD diagram indicated that synthesized samples were a single-phase product with the structure of holmium orthoferrite $\mathrm{HoFeO}_{3}$ (JCPDS no. 00-046-0115, space group Pbnm (62); $\mathrm{a}=5.282 \AA, \mathrm{b}=5.592 \AA, \mathrm{c}=7.608 \AA$ ) (Fig. 2). The increase in the annealing

\begin{tabular}{|c|c|c|c|c|c|c|c|}
\hline \multirow{2}{*}{$\mathrm{HoFeO}_{3}$} & \multirow{2}{*}{ I, (a.u.) } & \multirow{2}{*}{ FWHM, $\left(^{\circ}\right)$} & \multirow{2}{*}{$\mathrm{D},(\mathrm{nm})$} & \multicolumn{3}{|c|}{ Lattice constants, $(\AA)$} & \multirow{2}{*}{$\mathrm{V},\left(\AA^{3}\right)$} \\
\hline & & & & $\mathrm{a}$ & $\mathrm{b}$ & $\mathrm{c}$ & \\
\hline $750^{\circ} \mathrm{C}$ & 218.68 & 0.408 & 20.09 & 5.267 & 5.616 & 7.616 & 225.277 \\
\hline $850{ }^{\circ} \mathrm{C}$ & 238.70 & 0.480 & 23.97 & 5.271 & 5.605 & 7.583 & 224.032 \\
\hline
\end{tabular}
temperature led to an increase in the degree of crystallization, size of crystal particles, unit cell parameters, and a slight decrease in unit cell volume (Table 1). These results are consistent with the reported paper [27].

Table 1. Characteristics of crystalline $\mathrm{HoFeO}_{3}$ nanoparticles annealed at 750, and $850^{\circ} \mathrm{C}$. for $1 \mathrm{~h}$.

Raman spectra showed 3 strong peaks at 146.8, 514.1, and $598.4 \mathrm{~cm}^{-1}$ (Fig. 3a). The Raman active modes of the $\mathrm{HoFeO}_{3}$ were assigned based on the method recently proposed by Gupta et al. [31] for $\mathrm{RFeO}_{3}(\mathrm{R}=\mathrm{Tb}$, Dy, Ho, Er, Tm) compounds. The strongest peak at $146.8 \mathrm{~cm}^{-1}$ was attributed to the Ho-O vibration modes. The Raman bands above $200 \mathrm{~cm}^{-1}$ correspond to oxygen ions. The high-frequency mode in the $\mathrm{RFeO}_{3}$ crystal may be assigned to the internal vibration related to the mutual $\mathrm{Fe}-\mathrm{O}$ motion within the oxygen octahedron [20,31], which is present in this study at wavenumbers of 514.1 and $598.4 \mathrm{~cm}^{-1}$.

TEM images indicated that $\mathrm{HoFeO}_{3}$ nanoparticles were uniform (if considering individual particles). The mean sizes of particles after annealing at 750 and $850{ }^{\circ} \mathrm{C}$ were 20-30 nm and 20-40 nm, respectively (Fig. 3b, 3c, and Fig. 4). The particles are strongly aggregated at higher temperatures. According to the results of local X-ray microanalysis, the $\mathrm{HoFeO}_{3}$ sample contained only three elements: Ho, Fe, and $\mathrm{O}$ (Fig. 1b). The 
calculation of the quantitative composition demonstrated that the actual content of each element was quite close to the nominal composition (Table 2).

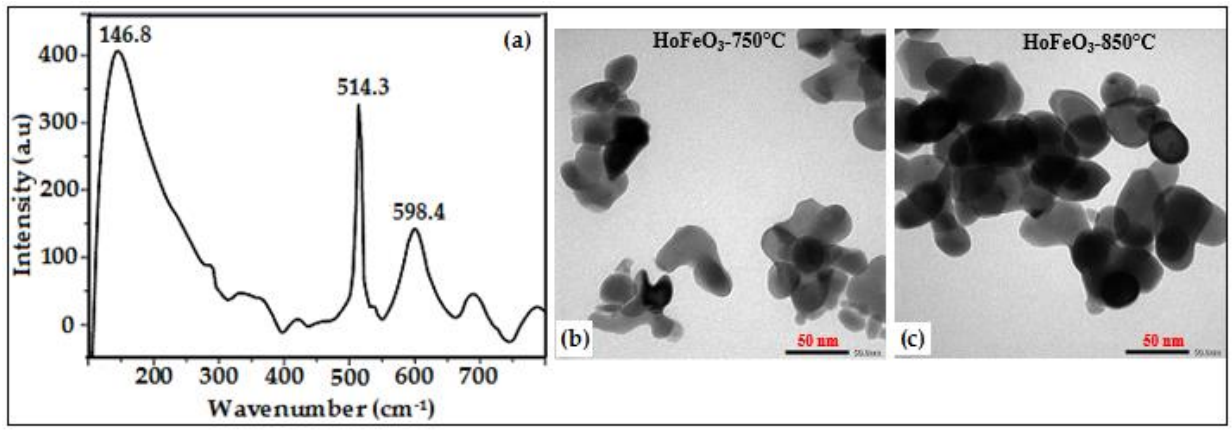

Fig. 3. Raman spectra of the $\mathrm{HoFeO}_{3}$ nanoparticles annealed at $850^{\circ} \mathrm{C}$ (a) and TEM images of the $\mathrm{HoFeO}_{3}$ nanoparticles annealed at 750 (b) and $850{ }^{\circ} \mathrm{C}$ (c) for $1 \mathrm{~h}$.
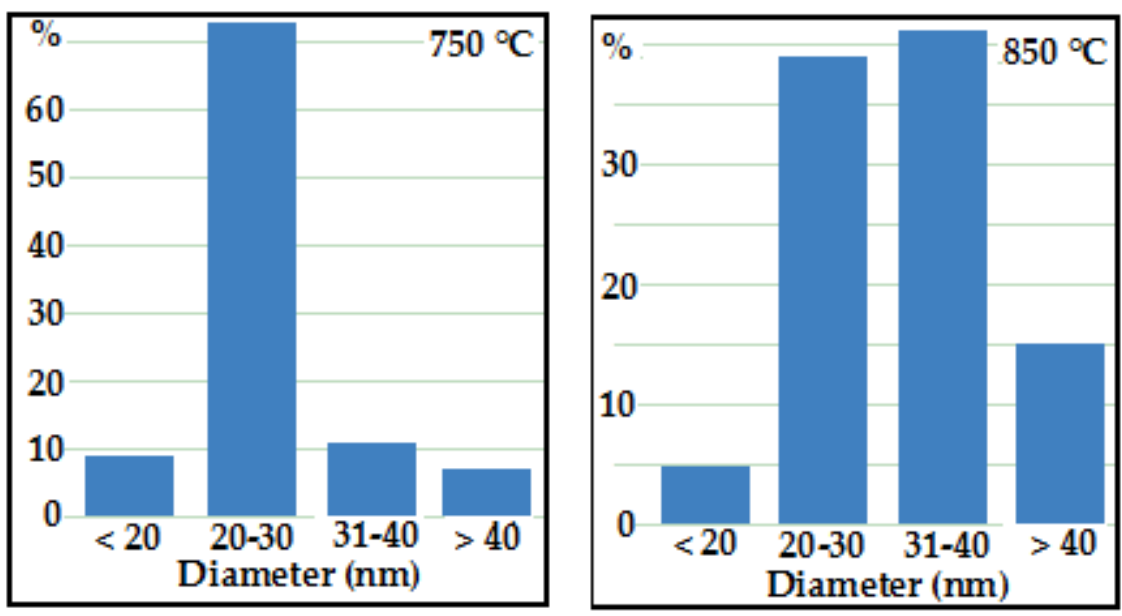

Fig. 4. Particle size distribution histogram of $\mathrm{HoFeO}_{3}$ powders annealed at 750 and $850^{\circ} \mathrm{C}$ for $1 \mathrm{~h}$.

Table 2. The theoretical and experimental weight percentage of $\mathrm{Ho}, \mathrm{Fe}$, and $\mathrm{O}$ of $\mathrm{HoFeO}_{3}$ sample annealed at $850^{\circ} \mathrm{C}$ as obtained by $\mathrm{EDX}$.

\begin{tabular}{|c|c|c|}
\hline Elements & Theoretical value (wt \%) & Experimental value (wt \%) \\
\hline Ho & 61.36 & 59.75 \\
\hline $\mathrm{Fe}$ & 20.78 & 20.07 \\
\hline $\mathrm{O}$ & 17.86 & 20.18 \\
\hline
\end{tabular}

The study of the $\mathrm{HoFeO}_{3}$ samples (annealing at 750 and $850{ }^{\circ} \mathrm{C}$ for $1 \mathrm{~h}$ ) on a vibration magnetometer at $100 \mathrm{~K}$ and $300 \mathrm{~K}$ showed that in a maximum field of 16,000 Oe, according to the shape of the hysteresis loop, the nanopowders of $\mathrm{HoFeO}_{3}$ are paramagnets (Fig. 5). The magnetic hysteresis curves of $\mathrm{HoFeO}_{3}$ annealed at 750 are 
similar to that of $\mathrm{HoFeO}_{3}$ annealed at $850{ }^{\circ} \mathrm{C}$. This observation is due to the same morphology (see Fig.3b-c) and insignificant changes in the crystalline size (see Table 1). Interestingly, the synthesized $\mathrm{HoFeO}_{3}$ nanoparticles presented lower $\mathrm{H}_{\mathrm{c}}$, and $\mathrm{M}_{\mathrm{r}}$ values $\mathrm{H}_{\mathrm{c}} \sim 20 \mathrm{Oe}, \mathrm{M}_{\mathrm{r}}<0.01 \mathrm{emu} / \mathrm{g}$ ), but higher $\mathrm{M}_{\mathrm{s}}$ compared to the orthoferrite nanoparticles of other rare-earth elements, such as $\mathrm{LaFeO}_{3}, \mathrm{YFeO}_{3}$, and $\mathrm{NdFeO}_{3}$ in similar conditions $[22,26,32]$ and compared to the data of other authors for similar objects [1, 17, 33] (Table 3). Typically, the $\mathrm{M}_{\mathrm{s}}$ value of obtained $\mathrm{HoFeO}_{3}$ was much higher than that of $\mathrm{HoFeO}_{3}$ prepared by the co-precipitation method using ethanol [27] (see Table 3). At $5 \mathrm{kOe}$, the magnetization of the $\mathrm{HoFeO}_{3}$ sample annealed at $850{ }^{\circ} \mathrm{C}$ increases when the temperature of the measurement decreases (Fig. 5a). The $\mathrm{HoFeO}_{3}$ orthoferrite samples with low coercive force, excessive magnetization, and high magnetization were investigated in this study. This material is paramagnetic and applicable in physics and biomedical, regarding quick responses to the external magnetic field [34].
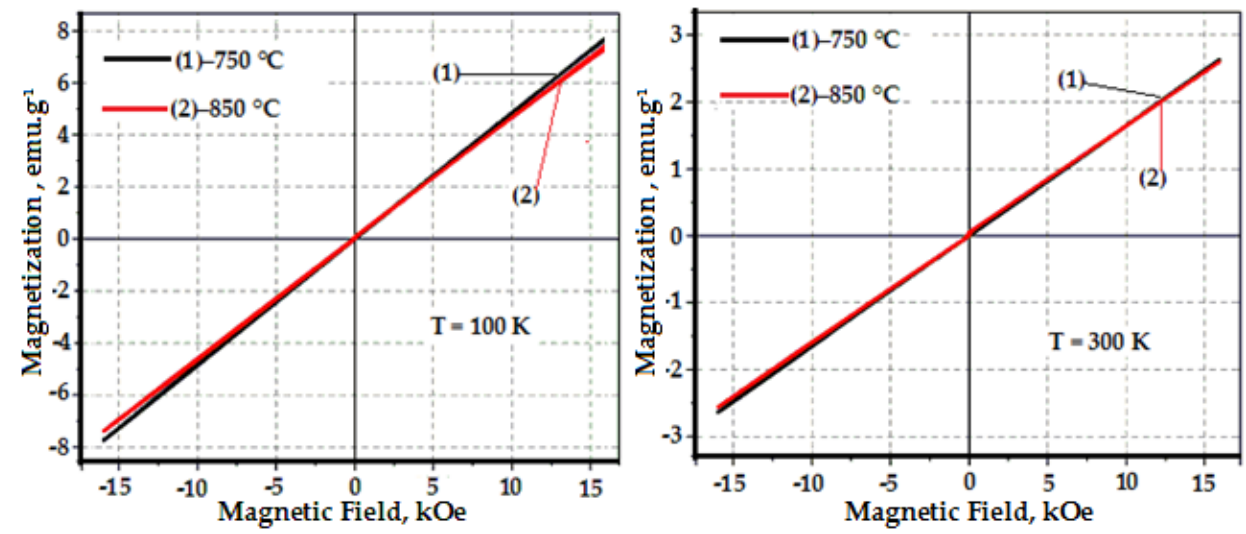

Fig. 4. Magnetization verses applied field plots of $\mathrm{HoFeO}_{3}$ nanoparticles at $100 \mathrm{~K}$ and $300 \mathrm{~K}$.

Table 3. Magnetic characteristics of $\mathrm{HoFeO}_{3}$ nanoparticles in this work and those of similar nanoparticles in the published literatures, at $300 \mathrm{~K}$.

\begin{tabular}{llll}
\hline $\mathrm{RFeO}_{3}$ & $\mathrm{M}_{\mathrm{r}}, \mathrm{emu} / \mathrm{g}$ & $\mathrm{H}_{\mathrm{c}}, \mathrm{Oe}$ & $\mathrm{M}_{\mathrm{s}}, \mathrm{emu} / \mathrm{g}$ \\
\hline $\mathrm{HoFeO}_{3}$ in this work & $<0.01$ & $20.05 \div 21.20$ & $\sim 2.73$ \\
\hline $\mathrm{YFeO}_{3},[22]$ & $0.19 \cdot 10^{-3}$ & 53.36 & 0.39 \\
\hline $\mathrm{LaFeO}_{3},[26]$ & $2.00 \cdot 10^{-2}$ & 42.53 & 0.24 \\
\hline $\mathrm{NdFeO}_{3},[32]$ & $68.0 \cdot 10^{-2}$ & 136.76 & 0.80 \\
\hline $\mathrm{HoFeO}_{3},[27]$ & $0.02 \div 0.04$ & $13.95 \div 22.70$ & $0.73 \div 0.79$ \\
\hline $\mathrm{LaFeO}_{3},[17]$ & $5.43 \cdot 10^{-4}$ & 1217.6 & $6.49 \cdot 10^{-3}$ \\
\hline $\mathrm{LaFeO}_{3},[1]$ & - & $25-125$ & $\sim 0.10$ \\
\hline $\mathrm{NdFeO}_{3},[33]$ & 1.5 & $\sim 850$ & 1.5 \\
\hline
\end{tabular}




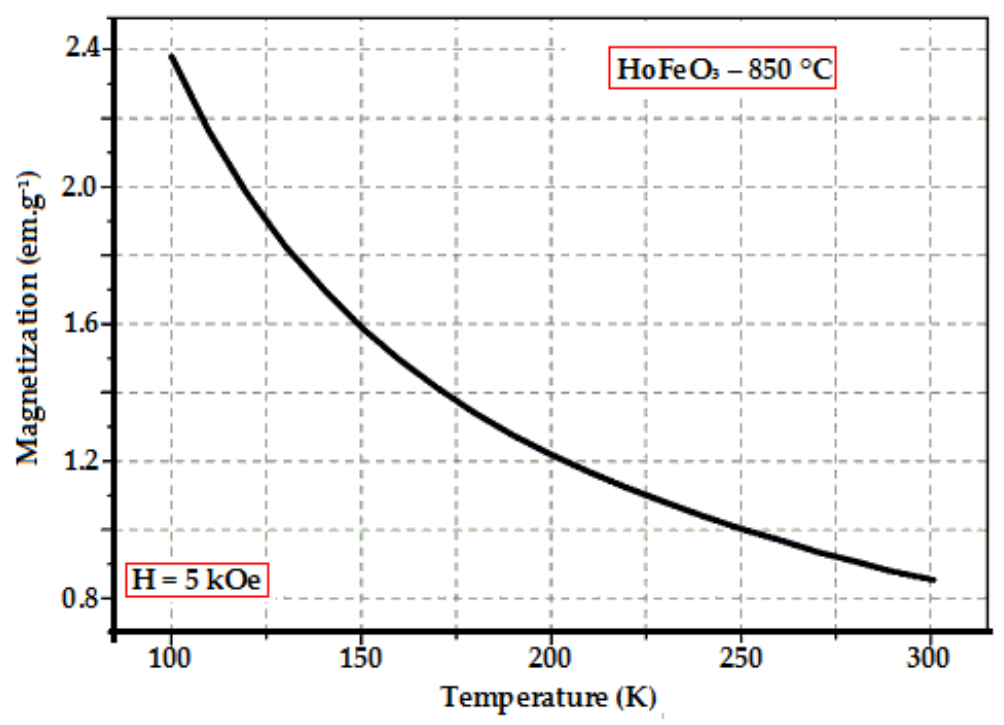

Fig. 5. Temperature dependence of zero-field-cold ( $\mathrm{ZFC}$ ) magnetization plot of $\mathrm{HoFeO}_{3}$ nanoparticles annealed at $850^{\circ} \mathrm{C}$ for $1 \mathrm{~h}$ (in the presence of $5 \mathrm{kOe}$ magnetic field).

\section{Conclusions}

In this study, $\mathrm{HoFeO}_{3}$ nanoparticles were synthesized by the simple coprecipitation method via a simple process. The first stage is the hydrolysis of Ho (III) and $\mathrm{Fe}$ (III) cations in boiling water with an aqueous ammonia solution. The second stage is the annealing at 750 and $850{ }^{\circ} \mathrm{C}$ for $1 \mathrm{~h}$. The synthesized $\mathrm{HoFeO}_{3}$ orthoferrite nanopowders exhibited a narrow hysteresis loop, small values of remanent magnetization and coercive force, but high magnetization, which is potential use as paramagnetic material in physics and biomedical.

\section{References}

[1] S. Phokha, S. Pinitsoontorn, S. Maensiri, S. Rujirawat: J Sol Gel Sci Tech, 71 (2014) 333-341.

[2] M. Yousefi, S. S. Zeid, M. K. Motlagh: Curr Chem Lett, 7 (2017) 23-30.

[3] P. Tang, X. Xie, H. Chen, Lv. Chunyan, Y. Ding: Ferr, 546 (2019) 181-187.

[4] J. W. Fergus: Sens. Act. B Chem, 123 (2007) 1169-1179.

[5] M. Abdellahi, A. S. Abhari, M. Bahmanpour: Cer Int, 42 (2016) 4637-4641.

[6] Sh. Nishiyama, I. Asako, Y. Iwadate, T. Hattori: Op J Inor Chem, 5 (2015) 7-11.

[7] O. Pekinchak, L. Vasylechko, I. Lutsyuk, Y. Vakhula, Y. Prots, W. CarrilloCabrera: Nano Res Lett, 11 (2016) 11:75.

[8] I. S. Kondrashkova, K. D. Martinson, N. V. Zakharova, V. I. Popkov: Rus J Gen Chem, 88 (2018) 2465-2471.

[9] A. Panchwanee, V. R. Reddy, A. Gupta: J Phys Conf S, 755 (2016) 012033.

[10] Z. Habib, K. Majid, M. Ikram, Kh. Sultan: App Phys A Mater Sci Proc, 122 (2016) 550.

[11] Zh. Zhou, L. Guo, H. Yang, Q. Liu, F. Ye: J All Compd, 583 (2014) 21-31. 
[12] L. Jiang, W. Liu, A. Wu, J. Xu, Q. Liu, G. Qian, H. Zhang: Cer Int, 38 (2012) 3667-3672.

[13] M. Shao, Sh. Cao, Y. Wang, Sh. Yuan, B. Kang, J. Zhang, A. Wu, J. Xu: J Cryst Gr, 318 (2011) 947-950.

[14] A. A. Rempel: Rus Chem Rev, 76 (2007) 435-461.

[15] Zh.-Qi. Wang, Ya.-Sh. Lan, Zh.-Yi. Zeng, X-R. Chen, Q-.F. Chen: Sol St Comm, 288 (2019) 10-17.

[16] T. Nishimura, S. Hosokawa, Y. Masuda, K. Wada, M. Inoue: J Sol Chem, 197 (2013) 402-407.

[17] C. Sasikala, N. Durairaj, I. Baskaran, B. Sathyaseelan, M. Henini: J All Compd, 712 (2017) 870-877.

[18] Y. J. Wu, J. Zhang, X. K. Chen, X. J. Chen: Sol St Comm, 151 (2011) 1936-1940.

[19] M. Bhat, B. Kaur, R. Kumar, P. A. Joy, S. D. Kulkarni, K. K. Bamzai, P. N. Rotru, B. M. Wanklyn: Nucl Instr Meth Phys Res B, 243 (2006) 134-142.

[20] Z. Habib, M. Ikram, K. Majid: Appl Phys A. Mater Sci Proc, 116 (2014) $1327-$ 1335 .

[21] A. T. Nguyen, I. Ya. Mittova, O. V. Almjasheva, S. A. Kirillova, V. V. Gusarov: Gl Phys Chem, 34 (2008) 756-761

[22] A. T. Nguyen, O. V. Almjasheva, I. Ya. Mittova, O. V. Stognei, S. A. Soldatenko: Inor Mater, 45 (2009) 1304-1308.

[23] T. A. Nguyen, M. V. Berezhnaya, Th. L. Pham, V. O. Mittova, M. Q. Vo, L. T. Tr. Nguyen, H. Tr. Do, I. Ya. Mittova, E. L. Viryutina: Rus J App Chem, 92 (2019) 498-504.

[24] A. T. Nguyen, H. D. Chau, T. Tr. L. Nguyen, V. O. Mittova, Tr. H. Do, I. Ya. Mittova: Nanosyst Phys Chem Math, 9 (2018) 424-429.

[25] A. T. Nguyen, V. N. T. Pham, T. Tr. L. Nguyen, V. O. Mittova, Q. M. Vo, M. V. Berezhnaya, I. Ya. Mittova, Tr. H. Do, H. D. Chau: Sol St Sci, 96 (2019) 105922.

[26] T. A. Nguyen, V. N. T. Pham, H. T. Le, D. H. Chau, V. O. Mittova, L. T. Tr. Nguyen, D. A. Dinh, T. V. Hao, I. Ya. Mittova: Cer Int, 45 (2019) 21768-21772.

[27] T. A. Nguyen, L. T. Tr. Nguyen, V. X. Bui, D. H. T. Nguyen, H. D. Lieu, L. M. T. Le, V. Pham: J All Compd, 834 (2020) 155098.

[28] A. G. Belous, E. V. Pashkova, V. A. Elshanskii, V. P. Ivanitskii: Inor Mater, 36 (2000) 343-351.

[29] N. Imanaka, Physical and Chemical Properties of Rare Earth Oxides, Binary Rare Earth Oxides, Kluwer Academic Publishers, (2004) 111-113.

[30] N. Kozo, H. Wakita, A. Mochizuki: Bull. Chem. Soc. Japan., 46 (1973) 152-156.

[31] H. C. Gupta, M. K. Singh, L. M. Tiwari: J Ram Spectr, 33 (2002) 67-70.

[32] T. A. Nguyen, V. Pham, Th. L. Pham, L. T. Tr. Nguyen, I. Ya. Mittova, V. O. Mittova, L. N. Vo, B. Tr. T. Nguyen, V. X. Bui, E. L. Viryutina: Cryst, 10 (2020) 219.

[33] P. R. Babu, R. Babu: Inter J Chem Tech Res, 9 (2016) 364-369.

[34] B. D. Cullity, C. D. Graham, Introduction to magnetic materials, $2^{\text {nd }}$ ed., Wiley, A John Wiley \& Sons, Inc., Publication, Canada, (2009) ISBN 978-0-471-47741-9.

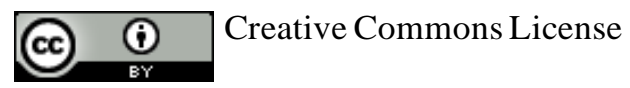

This work is licensed under a Creative Commons Attribution 4.0 International License. 